\title{
Study persistence and academic achievement as a function of the type of competing tendencies
}

\author{
Willy Lens \\ Marlies Lacante \\ Maarten Vansteenkiste \\ University of Leuven, Belgium
}

Dora Herrera

University of Lima, Peru

In order to understand and predict students' achievement and persistence at learning activities, many contemporary motivational models consider how much students are motivated for their school work. However, students' achievement and persistence might not only be affected by their amount of study motivation, but also by the motivation to engage in competing alternative activities, as suggested three decades ago by Atkinson and Birch in their "Dynamics of Action" (1970). Building on this line of theorizing, the present contribution indicates that it is not only instructive to consider the level of students' motivation for these competing activities, but also the type of activities they engage in, that is leisure vs. working activities. Two studies demonstrated that whereas time spent on working activities is inversely related to study motivation, attitude, persistence and academic achievement, such relationships were not found for leisure time engagement. Spending some time on leisure time activities does not interfere with optimal learning.

\section{Introduction}

Common sense assumes and educational research shows that individual differences in academic achievement result from differences in cognitive and other abilities, but also from differences in motivation. Parents and teachers alike quite often attribute disappointing school results to a lack of motivation, rather than to lacking abilities. They argue that more motivated

Part of this research was supported by grant OBPWO 98.11 (Ministry of Education, Flanders, Belgium). The third author's contribution was supported by a grant from Scientific Research Flanders (FWO-Vlaanderen). 
students spend more time and effort in their studies, which, in turn, would lead to higher levels of performance: The proverb "Practice makes perfect" may not always be true, but many underachieving students would indeed profit from devoting more time to their school work. However, as we hope to document in this contribution, one's level of persistence and quality of performance for an activity such as studying is not only determined by the strength of student motivation. Alternative interests and needs also matter.

Imagine Jan and Rob, two students, who started to study around 7 p.m.; Jan continued to do so till about 11 while Rob stopped already at 9 p.m. It is usually like that, Jan spends much more time at school work than Rob does. There may be many reasons for this difference in time spent studying. Maybe Rob needs less time to do a good job because he is more intelligent than his brother. For their parents it is quite evident that Jan is more motivated for his school work. The degree of persistence and effort is indeed very often understood as an index of motivation, also of student motivation (Pintrich \& Schunk, 2002). Highly motivated students will persist longer and will continue to put effort in the task, especially when they encounter unexpected obstacles. Also in organizational psychology and work motivation (Locke \& Latham, 1990) a positive linear relationship between strength of motivation and time spent working is assumed. Bob regularly leaves at 5 p.m. on Fridays to go for a swim with his children, while his colleague doesn't mind at all to stay till seven, even on Fridays. For their employer there is no doubt that Bob is much less motivated for his work that his colleague is.

In short, both these anecdotal examples and scientific claims suggest that persistence is a straightforward and linear indicator of people's strength of motivation. It is, however, our intention to show that, beyond the level or amount of study motivation, competing interests to engage in different activities than studying can explain variance in students' study time, but also in their academic achievements. Such a reasoning is rooted in the "Dynamics of Action", a more general motivational theory, of Atkinson and Birch (1970).

\section{Motivational dynamics in a continuous stream of behavior}

Atkinson and Birch (1970) suggested an alternative motivational explanation for the difference in individuals' persistence on a particular activity such as work or study. In doing so, they moved beyond the more static motivational analysis that characterized most motivational theories at that time, but that continues to be prominent nowadays. Instead, they defended a more dynamic approach of motivation, as the title of their work suggests. Indeed, the psychology of motivation is primarily concerned with the initiation (choice) of and the persistence in one particular goal-oriented activity, for example studying, and pays less attention to conflicting activities that might interfere with the engagement in and persistence at that particular activity. In contrast with such a view, Atkinson and Birch $(1970,1978)$ argued that the basic phenomenon to be explained by motivational psychology is not a series of isolated, episodic actions but a continuous stream of activities and changes in activities. When we look at a particular action as integrated in such a stream of activities, it becomes evident that the initiation of an activity (e.g., studying for an exam) defines at the same time the end or persistence of the foregoing activity (e.g., going for a run) and that the end of that activity coincides with the initiation of the following activity.

Atkinson and Birch (1978) further assume that a change from one activity to another expresses a change in the strength of underlying behavioral tendencies or motivations. The strongest tendency gets expressed in action. A change in activity will follow when an originally subdominant behavioral tendency becomes dominant or stronger than all other competing motivational tendencies, irrespective of the absolute strength of those tendencies. That means that the initiation of an activity at a certain moment in time and the duration or persistence of that action depends not only on the strength of the motivation for that action but also on the number and the strength of competing action tendencies. The more competing 
motivational tendencies there are and the stronger they are, the sooner the ongoing activity will be stopped and replaced by another activity, which motivational tendency has become stronger.

Translated to the academic context, in order to understand why some students persist in their studying and others give up more easily, it is not only important to look at these students' level or strength of motivation for studying, but also to consider the number and strength of competing action alternatives such as playing, sport, going to the movies, watching TV, or working in order to make some money. To further illustrate Atkinson and Birch' dynamic approach of motivation, image two students who are equally motivated for their studies. After having spent some time studying, both students' motivation to study will decrease over time due to the effect of a consummatory force1. To keep the illustration simple, we assume that for each of both students there is only one competing force, for example listening to music. One of both students is highly motivated to listen to music because he has just bought a brand new CD-player and each time he sees this apparatus on his table, his tendency to listen to music increases sharply (a strong instigating force). The second student has only an old portable radio. When he observes his radio or thinks about listening to music on the radio, this will also increases his tendency to listen to music. However, because of the low quality of the music produced by that radio, the CD-player has a much stronger instigating force than the radio. As a consequence, the tendency to listen to music for the first student is much more likely to become expressed, because this tendency becomes much sooner dominant over the tendency to study. Although both students' motivation to study is equal, the first student is more likely to stop studying and to switch to music listening sooner than the second student.

Such a dynamic motivational viewpoint provides an alternative explanation of behavioral persistence and changes in behavior; it shows how important it may be to look at the broader personal and social life context of students when trying to explain their educational choices, persistence, academic achievements and perhaps even their well-being. Many students have a variety of interests and live in several different worlds, thereby displaying multiple selves (Gergen, 1991). Indeed, students' school life is not lived in splendid isolation, to the contrary, it is part of a (more or less) complex dynamic system of which the different parts affect each other. These various interests, self-concepts and life domains may mutually reinforce each other, but they might also be conflictual. The fact that students face a broad variety of alternative activities that might disrupt their learning might be especially true given that we are currently living in a post-modern society (Gergen, 1991). Such a society is precisely characterized by the exponential growth in leisure opportunities, which might indirectly or directly interfere with adolescents' learning (Iyengar \& Lepper, 2000; Schwartz, 2000).

However, not only leisure time activities, but also engaging in a job to make some extra money might interfere with one's studying. This might especially be true for students form lower socio-economic levels and in developing countries, who experience financial problems. They might feel forced to take a part time job in order to be able to continue their education after secondary school. They have to divide their time between school, work, family, and friends. Herrera (2002) finds in her Peruvian data that this may be one of the important reasons for the big gap between educational planning at the end of high school and enacting those plans a year or even a few months later.

\section{Empirical evidence for a dynamic, motivational viewpoint}

Atkinson's and Birch' model has inspired a great deal of research. For instance, consistent with Atkinson and Birch' theorizing, Roede (1989, pp. 122-123) found in three groups of 7 th and 8 th graders (217 girls and 203 boys) that $41 \%, 35 \%$ and $44 \%$ of the variance in "investment for mathematics in the classroom" could be explained by the degree of investment in competing activities. The total explained variance was respectively $52 \%, 48 \%$ and $59 \%$. These results show that scores for competing behaviors turned out to be the best '(negative) predictor for students' investment in mathematics. The more students are attracted by competing activities, the less they invest in studying mathematics. Interest in competing 
behaviors was a much better (but negative) predictor of investment in math than the other measured motivational predictors, such as the motive to succeed and the attractiveness of mathematics as a school subject.

On a broader personality level, McCown, Petzel, and Rupert (1987), found a significant positive correlation of .60 between extraversion and procrastination. Because extraverted students, in general, need stimulation, want to discover and explore their surroundings, and actively seek challenges, they are likely to be interested in a broad variety of activities. However, these broad and varied interests might well prevent them from studying, and, hence, increase their study procrastination. Hence, their study procrastination is often not a result of low motivation or high fear of failure. Extraverted students lack time to study because other more exciting things come first.

Further evidence for the dynamic of action model comes from a study by Creten, Nijsmans, Lens, Douterlungne, and Cossy (1998; Creten, Lens, \& Simons, 2001). These authors analyzed the reasons for student motivation and especially de-motivation in a group of 733 students (from grade 9 to 12) in vocational high schools in Belgium where many pupils have important motivational problems. Among many other things, the participants were asked to indicate on a 4-point scale how much effort they spent for three different courses (i.e., a general theoretical course, French language course, and a practical course). Subsequently, students who reported to put very little or little effort in one of these courses were asked to select one or more reasons from a list of ten a priori determined reasons to explain their low effort. For all three courses the highest percentages was found for the category "other things to do" (percentages ranged from $41.1 \%$ to $52.9 \%$ ), suggesting that for many students other activities such as leisure are more important and might prevent them from working for school. For students who agreed that they put in "much" or "very much" effort, the most important reasons to do so for Theory, French and Practice were "diploma" $(63.00 \%, 63.2 \%, 80 \%)$ and "school grades" $(81.8 \%, 65.8 \%, 56.3 \%)$. A very small group said that they worked hard for school because they had "nothing else to do", reflecting some sense of boredom (percentages ranged from $2.6 \%$ to $5.8 \%$ ). In short, this study indicates that the presence of competing activities might interfere with students' investment in studying, and explain their low effort.

\section{Present research: Type of competing motivations matters}

The goal of the present contribution is to further test hypotheses derived from Atkinson and Birch model, and to build on their theoretical and empirical work in two ways. First, we do not only investigate whether the amount of time high school students spend engaging in particular competing activities affects their investment in school, as indexed by their motivation for school work and their attitude towards school in general, but also their school grades and drop-out. Second, we suggest that spending time at other activities than studying is not necessarily associated with lower motivation for studying, or with poorer performing scores. We argue that also the content or type of those competing activities matters. To put it differently, we explore whether the time spent in these competing alternative activities is always inversely related to learning outcomes or whether the nature of the relationship also depends on the type or content of those competing activities. Two different types of activities are considered, that is, time spent on leisure and work activities.

On the basis of the Dynamics of Action (Atkinson \& Birch, 1970), it can be hypothesized that the more time students spend on alternative activities than studying, the less they will be invested in their studies, and the worse they will perform, regardless of the content of the time-conflicting activity. However, we suggest that this relationship will vary according to the type of activities students are involved in: spending a certain amount of time on leisure activities might play a nurturing role for their study investment, because it helps them to relax and provides new energy to get (again) involved in the studying. However, being overly involved in leisure activities is, again, likely to interfere with one's studying. In contrast to this curvilinear prediction for leisure time activities, we expected adaptive learning to be related in 
a negative linear way with time spent on work activities. Because work activities are less likely to be experienced as relaxing, they were not expected to contribute to one's learning. Hence, the more time students spend on work, the lower their performances and school motivation, as would be predicted by Atkinson and Birch (1970). These hypotheses were tested in two studies that were conducted in Flanders, Belgium.

In a first study (Lacante et al., 2002) among first-year post-secondary school participants, who had gone through the complex educational choice process at the end of high school, we examinedthe relation between time spent on extra-curricular interests and activities and their academic achievement, motivation and attitude towards schooling. The latter two concepts were assessed with the Learning and Study Strategies Inventory or Lassi (Weinstein, Palmer, \& Schulte, 1987). "Attitude" refers to the relevance of schooling for students' life goals and to motivation for school work (e.g., "I don't care if I finish school as long as I find a husband/wife"; "I only study the subjects I like"; 8 items; $\alpha=.69$; for all attitude items the scoring is reversed). "Motivation" measures the willingness to perform specific tasks related to academic achievement such as reading text books, preparing for class (e.g., "I am up-to-date in my class assignments"; "I read textbooks assigned for my class"; 8 items; $\alpha=.78$ ). Engagement in extra curricular activities and interests were registered with two questions, one pertaining to engagement in leisure activities ("Besides studying, how much time are you engaged in sport, youth movement, social and cultural movements?") and one referring to time spent on a parttime job ("Besides studying, how much time are you engaged in doing some kind of part-time job?"). Concerning the question pertaining to leisure time activities, participants could choose between four options, that is, 'no time', '1-4 hours a week', '4-8 hours a week', and 'more than 8 hours a week'. Concerning the question pertaining to work time activities, three different options were offered, that is, 'no time', '1-8 hours a week', and 'more than 8 hours a week'. In addition to this self-reported information, which was collected at the start of the academic year, we also obtained information concerning their academic achievement 10 months later, at the end of the academic year. Four categories or levels of academic achievement were distinguished: students who succeeded in their first year, students who took all exams but failed, students who dropped out during exams (they didn't participate in all exams) and students dropping out before the exams started.

First, we consider the relation between time spent on extra curricular activities and students' motivation and attitude. The means for these two outcomes depending on the amount of time spent on leisure activities and work activities can be found in respectively Tables 1 and 2 .

Table 1

Motivation and attitude as a function of leisure time engagement a week

\begin{tabular}{lccccc}
\hline & \multicolumn{4}{c}{ Leisure time engagement } \\
\cline { 2 - 6 } & No $(n=810)$ & $1-4$ hours $(n=1150)$ & $5-8$ hours $(n=742)$ & $>8$ hours $(n=418)$ & $F$-value \\
\hline Attitude & $3.97 \mathrm{~B}$ & $4.04 \mathrm{~A}$ & $3.95 \mathrm{BC}$ & $3.89 \mathrm{C}$ & $11.47^{* * * *}$ \\
Motivation & $3.69 \mathrm{AB}$ & $3.74 \mathrm{~A}$ & $3.61 \mathrm{BC}$ & $3.54 \mathrm{C}$ & $15.81^{* * *}$ \\
\hline
\end{tabular}

Note. Means with the same letter do not differ significantly from each other; ${ }^{* * *} p<.001$.

Table 2

Motivation and attitude as a function of working time engagement a week

\begin{tabular}{lcccc}
\hline & \multicolumn{4}{c}{ Working time engagement } \\
\cline { 2 - 5 } & No $(n=2436)$ & $1-8$ hours $(n=494)$ & $>8$ hours $(n=189)$ & $F$-value \\
\hline Attitude & $4.01 \mathrm{~A}$ & $3.93 \mathrm{~A}$ & $3.80 \mathrm{~B}$ & $17.15^{* * * *}$ \\
Motivation & $3.70 \mathrm{~A}$ & $3.59 \mathrm{~B}$ & $3.46 \mathrm{C}$ & $20.56^{* * *}$ \\
\hline
\end{tabular}

Note. Means with the same letter do not differ significantly from each other; $* * * p<.001$. 
Analyses of variance pointed out that attitude and motivation are significantly related to the amount of free time engagement and to the numbers of working hours besides studying (see $F$-values in Table 1 and 2, all $p \mathbf{s}<.001$ ). Follow-up post-hoc contrast-analyses further indicated that the relationship between leisure time engagement and work time engagement and both outcomes is different. Specifically, Table 1 shows that students with a leisure time engagement of 1 to 4 hours a week, have a significantly more positive attitude towards schooling compared to students spending no time to leisure activities. The scores for motivation were in the same direction, but both groups did not differ significantly from each other. Furthermore, students' attitude and motivation were only lower if they devoted either 5-8 hours or more than 8 hours a week to leisure. Hence, students' motivation and attitude was not inversely related to their time spent on leisure activities, as suggested by Atkinson and Birch (1970).

In contrast to these results, Table 2 shows that those students who are not working have the highest scores for attitude and motivation. For "attitude" the difference between those who do not work at all and those who work less than 8 hours a week is not significant, whereas students who work more than 8 hours a week score significantly lower for attitude compared to both other groups. The three groups did differ though from each other for motivation: the more time students spend on working, the lower their study motivation. This pattern of results is different from the one obtained for hours spent on leisure time activities. These findings confirm our hypothesis that not only the absolute time spent on extra curricular activities is relevant to understand students' motivation, but that we should also take into account the content of the extra curricular activities (leisure versus work).

In an attempt to show that the currently used measures of motivation and attitude are important outcomes, we first discuss the relationship between attitude and motivation and academic achievement. These results can be found in Table 3.

Table 3

Academic achievement as a function of students' attitude and motivation

\begin{tabular}{lccccc}
\hline & \multicolumn{5}{c}{ Academic achievement } \\
\cline { 2 - 6 } & $\begin{array}{c}\text { Drop out } \\
\text { before exams } \\
(n=254)\end{array}$ & $\begin{array}{c}\text { Drop out } \\
\text { during exams } \\
(n=812)\end{array}$ & $\begin{array}{c}\text { Fail } \\
(n=462)\end{array}$ & $\begin{array}{c}\text { Pass } \\
(n=1607)\end{array}$ & $F$-value \\
\hline Attitude & $3.77 \mathrm{C}$ & $3.92 \mathrm{~B}$ & $3.97 \mathrm{AB}$ & $4.05 \mathrm{~A}$ & $26.56^{* * * *}$ \\
Motivation & $3.49 \mathrm{C}$ & $3.55 \mathrm{BC}$ & $3.59 \mathrm{~B}$ & $3.78 \mathrm{~A}$ & $42.10^{* * *}$ \\
\hline
\end{tabular}

Note. Means with the same letter do not differ significantly from each other; ${ }^{* * *} p<.001$.

The relation between students' attitude and academic achievement is somewhat ambiguous (see Table 3). Students who drop out during their first year in college (before the final exams start) have a significantly less positive attitude than the three other groups. Students who pass the exams have the most positive mean attitude score, but it is not significantly different from the mean score in the failure group. Table 3 also shows a positive linear relation between students' motivation and their academic achievement. Successful students are significant more motivated than the other groups.

In a more direct investigation of the relationship between academic achievement and the amount of time spent on competing activities, we performed two chi-square statistics. The percentages of students who dropped out from their studies before and during the exam period, those who failed and passed the exams depending on their time spent on competing activities can be found in Tables 4 (leisure time) and 5 (working time). These two tables provide the bivariate frequency distribution for academic achievement and the amount of engagement in competing activities. 
Table 4

Row percentages of bivariate frequency distribution between leisure time engagement and academic achievement

\begin{tabular}{|c|c|c|c|c|c|c|c|c|c|c|}
\hline \multirow[b]{3}{*}{ Leisure time engagement } & \multicolumn{10}{|c|}{ Academic achievement } \\
\hline & \multicolumn{2}{|c|}{$\begin{array}{c}\text { Drop out } \\
\text { before } \\
\text { exam period }\end{array}$} & \multicolumn{2}{|c|}{$\begin{array}{c}\text { Drop out } \\
\text { during } \\
\text { exam period }\end{array}$} & \multicolumn{2}{|c|}{ Fail } & \multicolumn{2}{|c|}{ Pass } & \multicolumn{2}{|c|}{ Total } \\
\hline & $n$ & $\%$ & $n$ & $\%$ & $n$ & $\%$ & $n$ & $\%$ & $n$ & $\%$ \\
\hline Not & 87 & 10.6 & 242 & 29.6 & 111 & 13.6 & 378 & 46.2 & 818 & 25.9 \\
\hline $1-4$ hours & 91 & 7.8 & 279 & 24.0 & 163 & 14.0 & 630 & 54.2 & 1163 & 36.8 \\
\hline 4-8 hours & 48 & 6.4 & 191 & 25.4 & 124 & 16.5 & 389 & 51.7 & 752 & 23.8 \\
\hline$>8$ hours & 32 & 7.5 & 111 & 26.2 & 68 & 16.0 & 213 & 50.2 & 424 & 13.4 \\
\hline Total & 258 & 8.2 & 823 & 26.1 & 466 & 14.8 & 1610 & 51.0 & 3157 & 100 \\
\hline
\end{tabular}

Note. $\chi^{2}(9, n=3157)=24.65 ; p<.005 ; p h i=.09$.

Table 5

Row percentages of bivariate frequency distribution between working time engagement and academic achievement

\begin{tabular}{|c|c|c|c|c|c|c|c|c|c|c|}
\hline \multirow[b]{3}{*}{ Working time engagement } & \multicolumn{10}{|c|}{ Academic achievement } \\
\hline & \multicolumn{2}{|c|}{$\begin{array}{l}\text { Drop out } \\
\text { before } \\
\text { exam period }\end{array}$} & \multicolumn{2}{|c|}{$\begin{array}{l}\text { Drop out } \\
\text { during } \\
\text { exam period }\end{array}$} & \multicolumn{2}{|c|}{ Fail } & \multicolumn{2}{|c|}{ Pass } & \multicolumn{2}{|c|}{ Total } \\
\hline & $n$ & $\%$ & $n$ & $\%$ & $n$ & $\%$ & $n$ & $\%$ & $n$ & $\%$ \\
\hline Not & 167 & 6.8 & 632 & 25.7 & 346 & 14.1 & 1312 & 53.4 & 2457 & 77.9 \\
\hline $1-8$ hours & 50 & 9.9 & 142 & 28.1 & 85 & 16.8 & 228 & 45.1 & 505 & 16.0 \\
\hline$>8$ hours & 39 & 20.2 & 51 & 26.4 & 35 & 18.1 & 68 & 35.2 & 193 & 6.1 \\
\hline Total & 256 & 8.1 & 825 & 26.1 & 466 & 14.8 & 1608 & 51.0 & 3155 & 100 \\
\hline
\end{tabular}

Note. $\chi^{2}(6, n=3155)=62.25 ; p<.0001 ; p h i=.14$.

First, the overall chi-square statistic was found significant, $\chi^{2}(9, n=3157)=24.65, p<.005$. As can be noticed in Table 4, a greater percentage of students, spending 1 to 4 hours a week in leisure, passed their exams compared to what can be expected (54.2\% versus $51 \%$ in general). Furthermore, a greater percentage of students who do no spend any time at leisure activities at all dropped out before exams ( $10.6 \%$ versus $8.2 \%$ in general) and during the exams $(29.6 \%$ versus $26.1 \%$ in general) compared to what can be expected. Also, in this group $46.2 \%$ succeeded in the exams, which is less than the $51 \%$ in the total group. Similarly, students spending more than 4 hours a week in leisure activities failed more than can be expected $(16.5 \%$ and $16 \%$ versus $14.8 \%$ in general). In summary, taking 1 to 4 hours of leisure time relaxation a week seems to be more optimal than no relaxation at all or more than 4 hours a week. These results mirror the results obtained for the self-reported motivation and attitude scales.

The pattern of results for working time engagement was different. Concerning descriptive data, Table 5 shows that almost $78 \%$ of the participants do not have a part time job during the academic year, 16\% work not more than 8 hours a week. Furthermore, the chi-square statistic was highly significant, $\chi^{2}(6, n=3155)=62.25, p<.0001$. We can read in Table 5 that the more students work, the poorer their academic achievement is. In the group of students who do not have a paid job, $53.4 \%$ passed and $14.1 \%$ failed (versus $51 \%$ and $14.8 \%$ in general). Also, $6.8 \%$ of the students without a job dropped out before the exams (versus $8.1 \%$ in general). In contrast, only $35.2 \%$ of the students who work more than 8 hours passed (versus $51 \%$ in general); $18.1 \%$ failed (versus $14.8 \%$ in general), $20.2 \%$ dropped out before the exams (versus $8.1 \%$ in general). 
In summary, these data point to a similar conclusion as the findings obtained for the selfreported scales of motivation and attitude: they show that not only the amount of time spent at extra curricular activities matters but also the type of those activities (work versus leisure). The specific nature of the relation between time spent at extra curricular activities and academic achievement depends on the content of the extra curricular activity.

A second study (Buelens \& Lacante, 1998) confirms these results. At the start of the academic year 1996-1997, 1536 college freshmen filled in a questionnaire. The same questions concerning extra curricular activities as those in the previous study were presented to the students. At the end of the year, students' academic achievement was categorized in four groups: students who passed, those who failed and repeated the first year, those who failed and left the institute, and those who dropped out before the exams.

Table 6

Row percentages of bivariate frequency distribution between leisure time engagement and academic achievement

\begin{tabular}{|c|c|c|c|c|c|c|c|c|c|c|}
\hline \multirow[b]{3}{*}{ Leisure time engagement } & \multicolumn{10}{|c|}{ Academic achievement } \\
\hline & \multicolumn{2}{|c|}{$\begin{array}{c}\text { Drop out } \\
\text { before } \\
\text { exam period }\end{array}$} & \multicolumn{2}{|c|}{$\begin{array}{l}\text { Fail and } \\
\text { drop-out }\end{array}$} & \multicolumn{2}{|c|}{$\begin{array}{c}\text { Fail and } \\
\text { redo exams }\end{array}$} & \multicolumn{2}{|c|}{ Pass } & \multicolumn{2}{|c|}{ Total } \\
\hline & $n$ & $\%$ & $n$ & $\%$ & $n$ & $\%$ & $n$ & $\%$ & $n$ & $\%$ \\
\hline Not & 33 & 7.3 & 105 & 23.2 & 60 & 13.3 & 255 & 56.3 & 453 & 29.5 \\
\hline $1-4$ hours & 29 & 5.3 & 119 & 21.6 & 59 & 10.7 & 343 & 62.4 & 550 & 35.8 \\
\hline$>4$ hours & 16 & 3.0 & 122 & 22.9 & 63 & 11.8 & 331 & 62.2 & 532 & 34.6 \\
\hline Total & 78 & 5.1 & 346 & 22.5 & 182 & 11.9 & 929 & 60.6 & 1535 & 100 \\
\hline
\end{tabular}

Note. $\chi^{2}(6, n=1535)=12.42 ; p<.10 ; p h i=.09$.

Although the chi-square is only marginally significant for Table $6\left[\chi^{2}(6, n=1535)=12.42\right.$, $p<.10 ; p h i=.09$ ] the data show that in the group without engagement in leisure time, only $56.3 \%$ of the students pass, compared to $60.6 \%$ in general and $7.3 \%$ stopped their studies before the exams started (compared to $5.1 \%$ in general). More students who engage in leisure activities pass the exams than in general $(62.4 \%$ and $62.2 \%$ compared to $60.6 \%)$, and less of them drop out $(5.3 \%$ and $3 \%$ in stead of $5.1 \%)$

Table 7

Row percentages of bivariate frequency distribution between working time engagement and academic achievement

\begin{tabular}{|c|c|c|c|c|c|c|c|c|c|c|}
\hline \multirow[b]{3}{*}{ Leisure time engagement } & \multicolumn{10}{|c|}{ Academic achievement } \\
\hline & \multicolumn{2}{|c|}{$\begin{array}{c}\text { Drop out } \\
\text { before } \\
\text { exam period }\end{array}$} & \multicolumn{2}{|c|}{$\begin{array}{l}\text { Fail and } \\
\text { drop-out }\end{array}$} & \multicolumn{2}{|c|}{$\begin{array}{c}\text { Fail and } \\
\text { redo exams }\end{array}$} & \multicolumn{2}{|c|}{ Pass } & \multicolumn{2}{|c|}{ Total } \\
\hline & $n$ & $\%$ & $n$ & $\%$ & $n$ & $\%$ & $n$ & $\%$ & $n$ & $\%$ \\
\hline Not & 54 & 4.7 & 242 & 21.2 & 143 & 12.5 & 703 & 61.6 & 1142 & 74.7 \\
\hline $1-8$ hours & 20 & 6.7 & 72 & 24.1 & 30 & 10.0 & 177 & 59.2 & 299 & 19.6 \\
\hline$>-8$ hours & 4 & 4.5 & 31 & 35.2 & 9 & 10.2 & 44 & 50 & 88 & 5.8 \\
\hline Total & 78 & 5.1 & 345 & 22.6 & 182 & 11.9 & 924 & 60.4 & 1529 & 100 \\
\hline
\end{tabular}

Note. $\chi^{2}(6, n=1529)=12.71 ; p<.05 ; p h i=.09$. 
Table 7 shows a significant association between the numbers of hours students work and their academic achievement $\left(\chi^{2}(6, n=1529)=12.71, p<.05 ; p h i=.09\right)$. The more students work, the lower the number of students who pass the exams. In general $60.4 \%$ pass, from those working more than 8 hours only $50 \%$ pass. In this group (working more than 8 hours a week) $35.2 \%$ fail and leave the educational institute, compared to $22.5 \%$ of the total group. We cannot conclude that spending more time at extra curricular activities always goes together with poorer academic achievements. The relation depends on the specific content of the extra curricular activities.

A potentially important shortcoming of this research is the fact that it is a correlational study. Based on theoretical grounds, the negative correlation between the numbers of working hours and academic achievement is interpreted in a causal way. We must however be aware of the fact this correlation may be spurious. For example, the socio-economic and psycho-social backgrounds of pupils can be the reason for working more hours and obtaining lower academic achievements.

\section{Discussion}

Schools are no islands and students do not live in isolation from the rest of the world. To the contrary, many students are interested in and motivated for many other things than studying. These alternative activities take time and there are only 24 hours in a day and 7 days in a week. Time management is therefore an important aptitude, also for students (Vanheste, Lens, \& Vandenberghe, 2001). Students must learn how to divide their time over the different fields of interest, because spending too much time in competing activities might prevent them from studying and result in poorer achievement, as suggested by Atkinson and Birch (1970), more than three decades ago. Atkinson and Birch argued that people's engagement in a particular activity and their persistence at it do not only depend on the strength of the motivation for that particular type of activity (e.g., studying) but also on the number and strength of the competing action tendencies. In doing so, they adopted a more dynamic viewpoint towards motivation, because they did not consider activities (and their motivations) in isolation, but paid attention to the continual, dynamic interplay between behaviors over time, an issue that seems to be lacking in most contemporary motivational theories.

The present contribution was rooted in that work, and aimed to extend it. Rather than only considering how much time students spend on other activities than studying, we examined whether the type of activities they engage in would be differently related to their studying. While some activities (e.g., work) might interfere with one's studying and hamper achievement, some engagement in others (e.g., leisure) might not. Consistent with these suggestions, the present study found that the effect of spending time on extra curricular activities on learning and academic achievement indeed depends on the type or content of those activities (e.g., leisure versus work). Two studies indicated that devoting time to relaxing leisure activities may have positive effects on school learning and achievement.

To more fully understand this difference, future research should also look at the reasons students have for engaging not only in academic work but also in those alternative activities, as can be suggested on the basis of self-determination theory (Deci \& Ryan, 1985, 2000; Vansteenkiste, Simons, Soenens, \& Lens, 2004). It might well be that students engage in leisure time activities for very different reasons than they engage in part-time jobs. Because the latter is likely to be undertaken out of financial difficulties, students might feel more pressured or controlled to spend time to working activities. In contrast, leisure time activities are more likely to be undertaken out of intrinsic enjoyment or because they are experienced as personally meaningful, labeled autonomous motivations within self-determination theory. Hence, it might well be that the quality of students' motivation (i.e., autonomous $v s$. controlled) to engage in these competing activities is confounded with the type of competing activities they engage in. Hence, it remains unanswered whether the interfering effect of work on academic achievement, as found in the present studies, is due to the type of activity (i.e., work) itself, or rather to the reasons that guide students' engagement in such competing work activities. 
The importance of the quality of the motivation for these alternative activities has recently been demonstrated by Vansteenkiste, Lens, Dewitte, De Witte, and Deci (2004). In two studies of long-term unemployed people, they examined the well-being associates of being forced not to search for a job and having to spend time on competing activities versus spending time on competing activities for autonomous reasons, that is out of intrinsic pleasure of personal valuation of these competing activities. Autonomous motivation not-to-search positively predicted well-being and a positive experience of being unemployed. It was negatively related to a negative experience of one's unemployment time. Such relationships were not found for a controlled motivation not-to-search for a job. In short, it appears that the quality of unemployed people's motivation to engage in activities other than job searching matters to understand their well-being. Similarly, the quality of students' motivation to engage in activities other than studying might matter in addition to the type of activities (work $v s$. leisure) they engage in, as suggested by the present study.

\section{Notes}

1 Notably, this assumption is not in contradiction with the fact that students who start studying may initially become more intrinsically motivated by and interested in the content of learning material or the task at hand.

\section{References}

Atkinson, J.W., \& Birch, D. (1970). The dynamics of action. New York: Wiley.

Atkinson, J.W., \& Birch, D. (1978). Introduction to motivation (2nd edition). New York: Van Nostrand.

Buelens M., \& Lacante, M. (1998). Drop out in het hoger onderwijs van één cyclus. Een onderzoek naar de redenen van studiestaken bij eerstejaarsstudenten van de Katholieke Hogeschool Leuven [Drop out in higher education of one cycle. Research into the causes of drop out among first year students of the KHLeuven]. Unpublished master thesis, Katholieke Universiteit Leuven, Belgium.

Creten, H., Lens, W., \& Simons, J. (2001). The role of perceived instrumentality in student motivation. In A. Efklides, J. Kuhl, \& R.M. Sorrentino (Eds.), Trends and prospects in motivation research (pp. 37-45). Dordrecht: Kluwer Academic Publishers.

Creten, H., Nijsmans, I., Lens, W., Douterlungne, M., \& Cossey, H. (1998). Algemene vakken en beroepsleerlingen: Op dezelfde golflengte? Motivatie van leerlingen en functioneren van leerkrachten algemene vakken in het beroepssecundair onderwijs [Theoretical courses in vocational secondary education: Are they on the same wave-length?]. Leuven: Department of Psychology \& HIVA.

Deci, E.L., \& Ryan, R.M. (1985). Intrinsic motivation and self-determination in human behavior. New York: Plenum.

Deci, E.L., \& Ryan, R.M. (2000). The 'what' and 'why' of goal pursuits: Human needs and the self-determination of behavior. Psychological Inquiry, 11, 227-268.

Gergen, K.J. (1991). The saturated self: Dilemmas of identity in contemporary life. New York: Basic Books.

Herrera, D. (2002). Social insertion of high school graduates in Lima: A socio-psychological study. Unpublished doctoral dissertation, University of Leuven, Leuven, Belgium.

Iyengar, S.S., \& Lepper, M.R. (2000). When choice is demotivating: Can one desire too much of a good thing? Journal of Personality and Social Psychology, 79, 995-1006.

Lacante, M., Lens, W., De Metsenaere, M., Van Esbroeck, R., de Jaeger, K., de Coninck, T., \& Santy, L. (2002). Drop-out in het eerste jaar hoger onderwijs Dropout in the first year of higher education (Eindrapport OBPWO 98.11). Brussel/Leuven: Vrije Universiteit Brussel/Katholieke Universiteit Leuven.

Locke, E.A., \& Latham, G.P. (1990). A theory of goal setting and task performance. Englewood Cliffs, NJ: Prentice Hall.

McCown, W.G., Petzel, T., \& Rupert, T. (1987). An experimental study of some hypothesized behaviors and personality variables of college student procrastinators. Personality and Individual Differences, 8, 781-786. 
Pintrich, P.R., \& Schunk, D.H. (2002). Motivation in education: Theory, research, and applications (2nd edition). Upper Saddle River, NJ. Merrill-Prentice Hall.

Roede, E. (1989). Explaining student investment: An investigation of high school students' retrospective causal accounts of their investment in school. Amsterdam: SCO-University of Amsterdam.

Schwartz, B. (2000). Self-determination: The tiranny of freedom. American Psychologist, 55, 79-88.

Vanheste, T., Lens, W., \& Vandenberghe, R. (2001). Motivatie en leerstijlen bij eerstejaarsstudenten aan de universiteit [Motivation and learning styles among college freshmen]. Leuven: University of Leuven.

Vansteenkiste, M., Simons, J., Soenens, B., \& Lens, W. (2004). How to become a persevering exerciser? Providing a clear, future intrinsic goal in an autonomy supportive way. Journal of Sport and Exercise Psychology, 26, 232-249.

Vansteenkiste, M., Lens, W., De Witte, S., Dewitte, H., \& Deci, E.L. (2004). The 'why' and 'why not' of job search behavior: Their relation to searching, unemployment experience, and well-being. European Journal of Social Psychology, 34, 345-363.

Weinstein, C.E., Palmer, D.H., \& Schulte, C. (1987). Learning and study strategy inventory. Clearwater, FL: H \& H Publishing Company.

Dans le but de comprendre et de prédire la performance et la persistance des étudiants dans des activités d'apprentissage, plusieurs théories contemporaines de la motivation considèrent l'intensité de la motivation des étudiants à l'endroit de leur travail scolaire. Cependant, la performance et la persistance des étudiants peuvent dépendre non seulement de l'intensité de la motivation à l'étude, mais aussi de la motivation à s'engager dans des activités différentes, comme l'ont déjà suggéré Atkinson et Birch dans leur 'Dynamics of action' (1970). Se basant sur cette théorie, le présent article propose de considérer non seulement le niveau de motivation des étudiants pour ces activités différentes, mais aussi le type d'activité (loisir vs travail). Deux études démontrent que le temps passé au travail est inversement relié à la motivation et à la persistance à l'étude, à l'attitude (positive) envers l'étude et au rendement scolaire; une telle relation n'est pas apparue pour le temps consacré aux loisirs. Un certain temps de détente ne nuit pas à l'apprentissage optimal.

Key words: Academic achievement, Competing motivations, Dynamics of action.

Received: September 2004

Revision received: November 2004

Willy Lens. Department of Psychology, University of Leuven, Tiensestraat 102, B-3000 Leuven, Belgium; E-mail: Willy.Lens@psy.kuleuven.ac.be, Web site: www.psy.kuleuven.ac.be/motivtim

Current theme of research:

The motivational significance of perceived instrumentality and future time perspective (expectancy-value theories). Immigrants in higher education: Factors affecting educational choices and achievements. The difference between the motivation (what) and the regulation (why) of motivated behavior (self-determination theory). Achievement goal theory: Teachers and students as communicating vessels. The motivational antecedents and consequences of religiosity. Future time perspective, values, perceived instrumentality and self concept among adolescents in private and public high schools in Peru. 
Most relevant publications in the field of Psychology of Education:

Husman, J., \& Lens, W. (1999). The role of the future in student motivation. Educational Psychologist, 34, 113-125.

Simons, J., Dewitte, S., \& Lens, W. (2004). The role of different types of instrumentality in motivation, study strategies, and performance: Know what you learn, so you '1l know what you learn! British Journal of Educational Psychology, 74, 343-360.

Simons, J., Vansteenkiste, M., \& Lens, W., \& Lacante, M. (2004). Placing motivation and future time perspective theory in a temporal perspective. Educational Psychology Review, 16, 121-139.

Vansteenkiste, M., Simons, J., Lens, W., Sheldon, K.M., \& Deci, E.L. (2004). Motivating learning, performance, and persistence: The synergistic effects of intrinsic goal contents and autonomy-supportive contexts. Journal of Personality and Social Psychology, 87, 246-260.

Vansteenkiste, M., Simons, J., Lens, W., Soenens, B., Matos, L., \& Lacante, M. (2004). Less is sometimes more: Goal-content matters. Journal of Educational Psychology, 96, 755-764.

Marlies Lacante. Department of Psychology, University of Leuven, Tiensestraat 102, B-3000 Leuven, Belgium; E-mail: Marlies.Lacante@psy.kuleuven.ac.be, Web site: www.psy.kuleuven.ac.be/motivtim

\section{Current theme of research:}

The motivational significance of perceived instrumentality and future time perspective (expectancy-value theories). Immigrants in higher education: Factors affecting educational choices and achievements. The difference between the motivation (what) and the regulation (why) of motivated behavior (self-determination theory). Achievement goal theory: Teachers and students as communicating vessels. The motivational antecedents and consequences of religiosity. Future time perspective, values, perceived instrumentality and self concept among adolescents in private and public high schools in Peru.

Most relevant publications in the field of Psychology of Education:

Simons, J., Vansteenkiste, M., \& Lens, W., \& Lacante, M. (2004). Placing motivation and future time perspective theory in a temporal perspective. Educational Psychology Review, 16, 121-139.

Vansteenkiste, M., Simons, J., Lens, W., Soenens, B., Matos, L., \& Lacante, M. (2004). Less is sometimes more: Goal-content matters. Journal of Educational Psychology, 96, 755-764.

Maarten Vansteenkiste. Department of Psychology, University of Leuven, Tiensestraat 102 , B-3000 Leuven, Belgium; E-mail: aarten.Vansteenkiste@psy.kuleuven.ac.be, Web site: www.psy.kuleuven.ac.be/motivtim

\section{Current theme of research:}

The motivational significance of perceived instrumentality and future time perspective (expectancy-value theories). Immigrants in higher education: Factors affecting educational choices and achievements. The difference between the motivation (what) and the regulation (why) of motivated behavior (self-determination theory). Achievement goal theory: Teachers and students as communicating vessels. The motivational antecedents and consequences of religiosity. Future time perspective, values, perceived instrumentality and self concept among adolescents in private and public high schools in Peru.

\section{Most relevant publications in the field of Psychology of Education:}

Simons, J., Vansteenkiste, M., \& Lens, W., \& Lacante, M. (2004). Placing motivation and future time perspective theory in a temporal perspective. Educational Psychology Review, 16, 121-139.

Vansteenkiste, M., Simons, J., Lens, W., Sheldon, K.M., \& Deci, E.L. (2004). Motivating learning, performance, and persistence: The synergistic effects of intrinsic goal contents and autonomy-supportive contexts. Journal of Personality and Social Psychology, 87, 246-260.

Vansteenkiste, M., Simons, J., Lens, W., Soenens, B., Matos, L., \& Lacante, M. (2004)..Less is sometimes more: Goal-content matters. Journal of Educational Psychology, 96, 755-764. 
Dora Herrera. Department of Psychology, University of Lima, Av. Javier Prado Estez s/n Urb. Monterrico, Lima 33, Peru; E-mail: dherrera38@hotmail.com

Current theme of research:

The motivational significance of perceived instrumentality and future time perspective (expectancy-value theories). Immigrants in higher education: Factors affecting educational choices and achievements. The difference between the motivation (what) and the regulation (why) of motivated behavior (self-determination theory). Achievement goal theory: Teachers and students as communicating vessels. The motivational antecedents and consequences of religiosity. Future time perspective, values, perceived instrumentality and self concept among adolescents in private and public high schools in Peru.

\section{Most relevant publications in the field of Psychology of Education:}

Fontaine, J.R.J., Luyten, P., De Boeck, P., Corveleyn, J., Fernandez, M., Herrera, D., Ittzés, A., \& Tomcsanyi, T. (in press). Untying the knot of guit and shame: The structure of guilt and shame reactions based on situations based on situation and person variation in Belgium, Hungary, and Peru. Journal of Cross-Cultural Psychology.

Herrera D., \& Lens, W. (in press). Perspectivas de tiempo futuro, valores, instrumentalidad y auto-concepto entre los adolescentes de las escuelas secundarias provadas y publicas y las ubiversidade en Lima. Revista de Psicologia de la Universidad Catolica Argentina, 1.

Lens, W., Herrera, D., \& Lacante, M. (2004). The role of motivation and future time perspective in educational counseling. Psychologica, special issue, 169-180. 